\title{
ANALISIS PEMBELAJARAN MATA KULIAH AUDITING (KOMPENTENSI DALAM AUDITOR JUDGMENT)
}

\author{
Oleh \\ Ery Wibowo, SE, M.Si, Akt \\ Universitas Muhammadiyah Semarang \\ JI. Kasipah No.12 Semarang
}

\begin{abstract}
Abstrak.
Proses pembelajaran mata kuliah auditing tidak bisa dilepaskan dengan tuntutan dunia praktik. Penerapan ilmu Auditing sebagai dasar kompetensi bagi profesi Auditor dalam dunia praktik membutuhkan perspektif ilmu yang sangat luas. Pada prakteknya seorang Auditor tidak hanya cukup berbekal pemahaman secar a kognisi terhadap ilmu Auditing yang berbasis pada ilmu akuntansi semata. Tetapi juga harus dituntut memiliki kemampuan interaksi social (soft skill).Makalah ini merupakan studi pustaka untuk mencoba membuat alur dalam mendisain sebuah proses pembelajaran bagi mata kuliah auditing yang memiliki dasar kompetensi bagi profesi Auditor.
\end{abstract}

Kata kunci : pembelajaran, soft skill, audit djugment, kompentensi 


\section{PENDAHUEUAN}

\section{Latar Belakang Masalah}

Proses belajar mengaiar dalam dunia pendidikan di Indonesia hampir selalu menempatkan siswa sebagai pendengar pasif, yaitu duduk, datang, mencatat dikurangi berpikir. Pioses tersebut tidak memberikan kebebasan berpikir, bernalar, dan mengaplikasikan pengetahuan dalam berbagai konteks, sehingga dnak didik kurang atau tidak kreatif dan kritis. Aliran pendidikan kritis dalam dunia pendidikan khususnya akuntansi semakin membuka peluang-peluang untuk mengkritisi konsep maupun sistem lama yang ada dalam pendidikan akuntansi. Untuk itu, sistem pendidikan khususnya pendidikan akuntansi seharusnya dikembangkan sesuai dengan UUD 1945 dan UU Sisdiknas 2003, yaitu pendidikan yang menjadi media untuk mewujudkan suasana belajar dan proses pembelajaran sehingga tumbuh potensi holistik dirinya yang memiliki daya kritis, kreatifitas dan mentalitas terhadap lingkungan yang berada di sekitarnya.

Proses pembelajaran ilmu Auditing tidak bisa dilepaskan dengan tuntutan dunia praktik. Penelitian-penelitian empirik menemukan banyak sekali fakta tentang proses interaksi auditor saat mengambil keputusan. Professional auditor judgment merupakan hal yang sangat penting dalam pekerjaan audit. Semua proses pekerjaan audit sangat tergantung pada auditor judgment. Karena itu auditor judgment dilakukan pada setiap tahapan dalam pelaksanaan audit yaitu penerimaan perikatan, perencanaan audit, pelaksanaan pengujian audit, dan pelaporan audit. Untuk membuat auditor judgment perlu keahlian yang didapatkan melalui pembelajaran panjang yang dasar ilmu Auditingnya diperoleh melalui pembelajaran di kampus. Dari beberapa hasil penelitian dalam bidang audit menunjukkan bahwa ada berbagai variasi faktor individual yang mempengaruhi judgment dalam melaksanakan review selama proses pelaksanaan audit (Solomon dan Shields,1995), dan pengaruh faktor individual ini berubah-ubah sesuai dengan kompleksitas tugas Tan and Kao (1999), dan Libby (1995). Selain faktor individual juga dipengaruhi oleh factor Budaya local misalnya budaya ewuh pekewih din subosita.

Faktor determinan penting dalam auditor judgment tersebut merupakan faktor-faktor yang secara unik berhubungan dengan individu pembuat keputusan dan variabel-variabel yang merupakan hasil dari proses sosialisasi dan pengembangan masing-masing individu (Ford dan Richardson, 1994; Loe et.al., 2000; Larkin, 2000; Paolillo \& Vitell, 2002). Faktor-faktor individual tersebut meliputi variabelvariabel yang bisa merupakan ciri pembawaan sejak lahir (gender,umur, kebangsaan dan sebagainya), ataupun faktor organisasi, lingkungan kerja, profesi dan budaya.

Hasil-hasil penelitian empirik tentang determinan penting dalam auditor judgment tersebut menunjukkan bahwa penerapan ilmu Auditing sebagai dasar kompetensi bagi profesi Auditor dalam dunia praktik membutuhkan perspektif ilmu yang sangat luas. Pada prakteknya seorang Auditor tidak hanya cukup berbekal pemahaman secara kognisi terhadap ilmu Auditing yang berbasis pada ilmu akuntansi semata. Tetapi juga harus dituntut memiliki kemampuan interaksi social (soft skill).

Psikolog kawakan, David McClelland bahkan berani berkata bahwa faktor utama keberhasilan para eksekutif muda dunia adalah kepercayaan diri, daya adaptasi, kepemimpinan dan kemampuan mempengaruhi orang lain. Yang tak lain dan tak bukan merupakan soft skill.

Bisa dikatakan bahwa profesionalisme auditor merupakan gabungan dari kemampuan hard skill dan soft skill. Sehingga Auditor bisa menlankan tugas secara profesional, memiliki kemampuan menyeluruh diantaranya critical review, analytical skills, Critical Thinking, Time Management , Communication Skills, Decision Making skills, Research Skills, writing skills, learning skills, practical skills. Kemampuan tersebut berintegrasi pada diri auditor membentuk Professional auditor judgment. Menurut Dan M. Guy, dkk yang diterjemahkan oleh Paul A. Rajoe dan Ichsan Setyo Budi,

"Agar dapat pertanggungjawaban dengan benar, seorang auditor harus memiliki tingkat kemampuan profesional yang tinggi. Sesuai dengan standar, 
kemampuan profesional meliputi ketaatan pada standar perilaku; pengetahuan, keterampilan, dan disiplin ilmu; hubungan komunikasi antar karyawan; pendidikan yang berkelanjutan serta keahlian professional." (Auditing, 2003)

Hasil-hasil penelitian empiris di dunia praktik merupakan tantangan bagi jurusan akuntansi untuk dapat mendisain sebuah proses pembelajaran bagi auditor agar dapat memiliki kompetensi yang mampu memenuhi tuntutan praktis sekaligus memahami audit dari segala aspek secara menyeluruh.

\section{PERMASALAHAN}

Apakah disain pembelajaran mata kuliah auditing sudah mempertimbangkan tuntutan dunia praktik auditing?

\section{TUJUAN DAN MANFAAT \\ PENELITIAN}

1. Memperkaya khasanah teori pembelajaran mata kuliah auditing

2. Menemukan bentuk pembelajaran mata kuliah auditing yang memiliki kompetensi dalam profesi auditor.

\section{PEMBAHASAN}

1. Proses Kognisi Auditor Judgment Hogart (dikutip oleh Jamilah, dkk, 2007) mengartikan judgment sebagai proses kognitif yang merupakan perilaku pemilihan keputusan. Jamilah dkh (2007) mengemukakan bahwa:

Judgment merupakan suatu proses yang terus menerus dalam perolehan informasi (termasuk umpan balik dari tindakan sebelumnya), pilihan untuk bertindak atau tidak bertindak, penerimaan informasi lebih lanjut.

Pertimbangan auditor (auditor judgments) sangat tergantung dari persepsi mengenai suatu situasi. Judgment, yang merupakan dasar dari sikap profesional, adalah hasil dari beberapa faktor seperti pendidikan, budaya, dan sebagainya, tetapi yang paling signifikan dan tampak mengendalikan semua unsur seperti pengalaman adalah perasaan auditor dalam menghadapi situasi dengan mengingat keberhasilan dari situasi sebelumnya. Judgment adalah perilaku yang paling berpengaruh dalam mempersepsikan situasi, dimana determinan utama sifatnya kadang kontekstual tergantung dari banyak factor yang mempengaruhinya. kualitas Judgment dapat dibentuk dan di arahkan dalam sebuah proses pembelajaran yang benar. Pembentukan prilaku ini tentu dimulai dari lingkungan pendidikan diajarkan secara dini dimulai sejak pembelajaran mata kuliah auditing.

\section{Determinan Auditor Judgment Yang Perlu Dipertimbangkan Dalam Proses Pembelajaran}

Menurut hasil-hasil penelitian empirik menunjukkan ada beberapa determinan penting yang perlu dicermati dalam mendisain atau merancang sebuah proses pembelajaran mata kuliah auditing. Determinan tersebut sangat erat kaitanya dengan keberhasilan proses pembelajaran mata kuliah Auditing. Out put dari proses pembelajaran Auditing harus mampu mengatasi kendala-kendala kontekstual yang muncul ketika seorang auditor membuat Auditor judgment. Beberapa determinan penting tersebut antara lain :

a. Independensi

Kepercayaan terhadap diri sendiri. Seorang Auditor dapat dikatakan independen bila memiliki sikap mental yang bebas dari pengaruh, tidak dikendalikan oleh pihak lain, tidak tergantung pada orang lain. Independensi juga berarti adanya kejujuran dalam diri auditor dalam mempertimbangkan fakta dan adanya pertimbangan yang tidak memihak dalam diri auditor dalam merumuskan dan menyatakan pendapatnya.

Implementasinya pada proses pembelajaran adalah merancang ssbuah proses belajar yang mampu menghasilkan sikap mental yang mandiri dan jujur.

b. Kompleksitas Tugas

Kompleksitas tugas merupakan tugas yang tidak terstruktur, membingungkan dan sulit (Sanusi dalam Cecilia, 2007). Auditor selalu dihadapkan dengan tugastugas yang kompleks, berbeda-beda dan saling terkait satu dengan yang lainnya. Beberapa tugas audit dipertimbangkan sebagai tugas dengan kompleksitas yang tinggi dan sulit, sementara yang 
lain mempersepsikannya sebagai tusa yang mudah.

Terdapat dua aspek penyusunan dari kompleksitas tugas, yaitu tingkat kesulitan tugas dan struktur tugas. Tingkat sulitnya tugas selalu dikaitkan dengan banyaknya informasi tentang tugas tersebut, sementara struktur adalah terkait dengan kejelasan informasi (information clarity). Menurut Bonner (1994) dalam Jamilah (2007), proses pengolahan informasi terdiri dari tiga tahapan, yaitu: input, proses, output. Pada tahap input dan proess, kompleksitas tugas meningkat seiring bertambahnya faktor petunjuk. Terdapat perbedaan antara pengertian banyaknya petunjuk yang diadakan (number of cues available) dengan banyaknya petunjuk yang terolah (number of cues processed). Banyaknya petunjuk yang ada, seorang pembuat keputusan harus berusaha melakukan pemilahan terhadap petunjuk petunjuk tersebut dan ke mudian mengintegrasikannya ke dalam suatu pendapat. Keputusan bisa diberikan segera bila banyak petunjuk yang diamati tidak meninggalkan batas-batas kemampuan dari seorang pembuat keputusan (Chung dan Monroce dalam Jamilah, 2007).

Tekanan kerja Ada dua jenis kompleksitas yang berpengaruh pada pengembangan sistem, yaitu kompleksitas tugas dan kompleksitas sistem (Indriantoro, 2000) Kompleksitas tugsa berasal dari lingkungan pemakai dan berkaitan dengan ambiguitas dan ketidakpastian yang ada di sekitar dunia bisnis. Kompleksitas sistem berasal dari lingkungan pengembang dan berkaitan dengan ambiguitas dan ketidakpastian yang terjadi di sekitar pengembangan sistem.

\section{c. Tekanan Kerja (stress)}

Tekanan kerja merupakan suatu pola emosi dan reaksi psikologis yang terjadi dalam situasi dimana seseorang merasa terancam atas tujuan penting yang mungkin akan ditemui. Stress melibatkan hubungan seseorang dengan lingkungan. Dalam penelitian empirik tekanan kerja auditor ini dapat mosupengaruhi seorang auditor dalam mengambil keputusan (auditor judgment), bahkan secara potensi menimbulkan keinginan seorang Auditor berpindah kerja.

\section{d. Tekanan Anggaran Waktu}

De zoort (2002) mendefinisikan tekanan anggaran waktu sebagai bentuk tekanan yang muncul dari keterbatasan sumber daya yang dapat diberikan untuk melaksanakan tugas. Sumber daya dapat diartikan sebagai waktu yang digunakan auditor dalam pelaksanaan tugasnya. Tekanan anggaran waktu adalah keadaan yang menunjukkan auditor dituntut untuk melakukan efisiensi terhadap anggaran waktu yang telah disusur atau terdapat pembatasan waktu dan anggaran yang sangat ketat dan kaku (Sososutikno, 2003).

\section{Pembelajaran}

Konsep atau pengertian belajar sangat beragam dan tergantung dari sisi pandang setiap orang yang mengamatinya. Belajar merupakan salah satu konsep menarik dalam teori-teori psikologi dan pendidikan, sehingga para ahli memberi bermacammacam pengertian mengenai belajar. Belajar merupakan kegiatan individual, kegiatan yang dipilih secara sadar karena seseorang mempunyai tujuan individual tertentu (Suwarjono, 1991). Belajar adalah proses perubahan perilaku akibat interaksi individu dengan lingkungan (Ali, 1992 dalam Hanifah dan Syukriy) dan merupakan suatu proses usaha yang dilakukan individu untuk memperoleh suatu perubahan tingkah laku yang baru secara keseluruhan, sebagai pengalaman individu itu sendiri dalam interaksi dengan lingkunganya (Slameto, 1991 dalam Hanifah dan Syukriy, 2001). Ahmadi (1993) dalam Hanifah dan Syukriy (2001) lebih jauh menyatakan bahwa belajar adalah suatu perubahan di dalam diri manusia, sehingga apabila setelah belajar tidak terjadi perubahan dalam diri manusia, maka tidaklah dapat dikatakan padanyd telah berlangsung proses belajar.

Belajar merupakan akibat adanya interaksi, stimulus dan respon (Slavin, 2000:143). Seseorang dianggap telah belajar sesuatu jika dia dapat menunjukkan perubahan perilakunya. Menurut teori ini dalam belajar yang penting adalah input 
yang berupa stimulus dan output yang berupa respon. Stimulus adalah apa saja yang diberikan guru/dosen kepada anak didik/mahasiswa, sedangkan respon berupa reaksi atau tanggapan pebelajar terhadap stimulus yang diberikan oleh guru tersebut. Proses yang terjadi antara stimulus dan respon tidak penting untuk diperhatikan karena tidak dapat diamati dan tidak dapat diukur. Yang dapat diamati adalah stimulus dan respon, oleh karena itu apa yang diberikan oleh dosen (stimulus) dan apa yang diterima oleh pebelajar (respon) harus dapat diamati dan diukur. Teori ini mengutamakan pengukuran, sebab pengukuran merupakan suatu hal penting untuk melihat terjadi atau tidaknya perubahan tingkah laku tersebut. Faktor lain yang dianggap penting dalam proses pembelajaran adalah penguatan (reinforcement). Bila penguatan ditambahkan (positive reinforcement) maka respon akan semakin kuat. Begitu pula bila respon dikurangi/dihilangkan (negative reinforcement) maka respon juga semakin kuat. Pembelajaran merupakan proses belajar yang terus menerus.

\section{a. Soft Skil dan Hard skill}

Out put dari proses pembelajaran saat ini akan dinilai berhasil bila peserta didik dapat memperoleh kemampuan baik hard skill maupun soft skill. Hard skill berupa pengetahuan koqnisi pembelajar, sedangkan kemampuan soft skill dikelompokkan ke dalam ke tiga golongan yaitu daya kritis, kreativitas, dan mentalitas.

\section{b. Sikap Kritis}

Sebagai paham keilmuan, teori kritis dikembangkan dari konsepsi kritis terhadap pemikiran dan pandangan yang sebelumnya. Sedikitnya, ada dua konsepsi perihal "kritis" yang perlu diklarifikasi (Guba, 1990). Pertama, "kritis internal" terhadap analisis argumen dan metode yang digunakan dalam berbagai penelitian. Hal ini menunjukkan bahwa argumen yang ada harus didialektikaka dengan argumen yang lain, sehingga memunculkan argumen yang lebih baru. Dan argumen yang baru tersebut harus didialektika dengan argumen yang baru lagi, sehingga sikap kritis tidak akan pernah berhenti. Kedua, makna "kritis" dalam reformulasi masalah logika. Logika bukan semata-mata pengaturan formal dan kriteria internal dalam pengamatan, tetapi juga melibatkan bentuk-bentuk khusus pemikiran yang difokuskan pada skeptisisme dalam pengertian rasa ingin tahu terhadap institusi sosial dan konsepsi tentang realitas yang berkaitan dengan ide, pemikiran, dan bahasa melalui kondisi sosial historis. Reformulasi masalah logika juga dilampaui dengan adanya pemikiran intuitif serta pencarian sesuatu yang sulit dikaitkan dengan logika, tetapi hal tersebut merupakan suatu logika tanpa atau belum terdapat pembuktian secara ilmiah.

\section{c. Kreatifitas}

Kreatifitas menurut Kamus Besar Bahasa Indonesia (KBBI) adalah kemampuan untuk mencipta atau perihal berkreasi. Kreatifitas bukan sebuah kemampuan tunggal yang bisa digunakan seseorang dalam setiap aktivitasnya, tetapi kecerdasan yang majemuk. Ada tiga bahan dasar kreatifitas (Teresa dalam Goleman dkk, 2005), yaitu: Keahlian dalam bidang khusus berupa ketrampilan dalam hal tertentu, seperti linguistis, logis, spasial, musikal, kinestetis, intrapersonal, dan interpersonal. Ketrampilan ini merupakan penguasaan dasar dalam suatu bidang. 2. Ketrampilan berpikir kreatif. Ketrampilan berpikir kreatif ini mencakup kemampuan untuk membayangkan rentang kemungkinan yang beragam, tekun dalam menangani persoalan, dan memiliki standar kerja yang tinggi. 3 . Motivasi intrinsik. Dorongan untuk melakukan sesuatu semata demi kesenangan melakukannya bukan karena hadiah atau kompensasi. Untuk menuju pada kreatifitas harus melakukan dan mengupayakan pikiran, sikap, dan tindakan yang positif serta membuang sesuatu hal yang negatif.

Orang kreatif bukan saja terbuka terhadap segala jenis pengalaman baru, tetapi juga berani mengambil risiko. Menemukan keberanian adalah merangkul kecemasan dan mengambil langkah selanjutnya adalah penting bagi kreatifitas jenis apa pun. Cemas adalah kaki tangan kreatifitas. Kecemasan biasanya terjadi bila membuat sesuatu yang diluar kebiasaan atau diluar aturan dan membuat kebiasaan serta aturan baru yang lebih baik daripada sebelumny'a. Akan tetapi, mengakui kecemasan dan kemauan untuk mengandengnya yang penting. Pikiran yang dipenuhi oleh kekhawatiran menganggu orang berfokus pada pekerjaan. Kecemasan 
semecte ini merakm pembunuh kreatifitas. Semakin terbebas dari pikiran penghambat, semakin mudah memusatkan diri dalam upaya mengembangkan kreatifitas dari sumber sejati satu-satunya, yaitu diri sendiri.

Kreatifitas pada shimya harus tumbuh dari perpaduan unik antara ciri kepribadian dan kecerdasan pribadi yang menjadi scseorang berbeda. Untuk mengembangkan dan meningkatkan kreatifitas, harus dipupuk dan dikembangkan jiwa kreatif. Ada empat unsur dasar pembentuk jiwa kreatif. Unsurunsur tersebut sudah melekat pada semua orang sejak lahir, tetapi sering jiwa tersebut tidak diasah sehingga tumpul dalam berkreatifitas. Tanpa sifat-sifat tersebut adalah sulit untuk menjadi kreatif. Pertama, cari tahu. Rasa ingin tahu adalah kebutuhan utama jiwa kreatif. Tanpa adanya minat pada apa yang bisa diberikan dunia ini, apa yang menjadikan segala sesuatu berfungsi, gagasan apa yang dimiliki orang lain, seseorang tak memiliki alasan untuk kreatif. Rasa ingin tahu yang mendorong seseorang menyelidiki bidang baru atau mencari cara mengerjakan sesuatu dengan lebih baik. Rasa ingin tahu mengendalikan dorongan mencipta, bereksperimen, dan membangun.

Kedua, olah keterbukaan.

Keterbukaan adalah vital dalam jiwa kreatif. Dengan bersikap terbuka, seseorang mampu menerima ide baru dan memadukannya ke dalam otak. Orang-orang kreatif bersifat terbuka terhadap gagasan, manusia, tempat, dan hal-hal baru. Keterbukaan juga terkait kesadaran akan dan tanggap terhadap kebetulan-kebetulan dalam hidup. Ketiga, keberanian menanggung risiko. Tanpa adanya keberanian menanggung risiko, kebanyakan prestasi kreatif takkan pernah terwujud. Keberanian menanggung risiko ini terkait erat dengan zona kenyamanan. Jika berani menanggung risikn, seseorang akan mampu meninggalkan zona kenyamanan untuk bertemu dengan gagasan, pribadi, dan informasi baru yang akan melejitkan kreatifitas. Keempat, energi. Sifat pamungkas yang dibutuhkan jiwa kreatif adalah energi. Tanpa adanya energi mental yang mencukupi, perburuan kreatif seseorang akan cacat karena kekeliruan logika dan pemikiran jangka pendek yang mustahil bisa diterapkan. Tanpa adanya energi fisik yang mencukupi, gagasan kreatif tak bisa dijalankan atai terkining abo lemari dan berkarat.

Selain dibutuhkan jiwa yang kreatiî juga diperlukan bahan dasar kreatifitas. Kemampuan untuk membuat keputusan intuitif merupakan bahan dasar kreatifitas (Goleman dkk, 2005). Intuisi beranti menghapus kontrol atas pikiran dan mempercayai visi alam tak sadar. Instuisi mempunyai keberanian sendiri karena ia berlandaskan pada kemampuan alam tak sadar untuk mengorganisasi informasi menjadi ide-ide baru yang tak terduga. Dalam proses berpikir intuisi ini, pemikiran secara logika harus ditanggalkan. Kreatifitas yang didasari atas kreatif rasional dan kreatif intuitif harus diimplementasikan pada sesuatu yang nyata untuk menjadikan sesuatu produk yang baru. Hal ini dilakukan dengan mengaitkan sesuatu hal (bagian tanaman, tumbuhan dan lainnya) dengan hal lain (sesuatu produk) yang mampu membuat nilai tambah dan berdaya guna serta orisinal. Upaya tersebut dilakukan dengan memilah dan memilih bagian dari sesuatu untuk dibuat sesuatu yang inovatif. Dalam pengajaran akuntansi, Bulo (2002) mengidentifikasi salah satu keluaran dari proses pengajaran akuntansi adalah kemampuan intelektual yang terdiri dari ketrampilan teknis dasar akuntansi dan kapasitas untuk berpikir kritis dan kreatif. Kreatifitas dapat meningkatkan kepercayaan dan prestasi anak didik. Anak didik kreatif memiliki peluang lebih tinggi untuk memecahkan masalah dari sudut pandang berbeda, sehingga solusi terbaik selalu muncul. Kreatifitas memungkinkan anak didik beradaptasi dan merespon perubahan lingkungan, sehingga kinerja dapat ditingkatkan.

Pembelajaran dengan menggunakan pendekatan konsep berarti siswa dibimbing memahami suatu bahasan melalui pemahaman konsep yang terkandung di dalamnya. Dalam proses pembelajaran tersebut penguasaan konsep dan subkonsep yang menjadi fokus. Dengan beberapa metode siswa dibimbing untuk memahami konsep.

\section{d. Mentalitas}

Menurut Kamus Besar Bahasa Indonesia (KBBI) merupakan keadaan dan aktivitas jiwa (batin) atau cara berpikir dan berperasaan. Keadaan dan aktivitas jiwa atau 
cara berpikir dan berperasaan idak hanya ditentukan berdasarkan intelligentia quotient (IQ), tetapi juga emotional quotient (EQ) dan spiritual quotient (SQ). IQ merupakari cermin dari kecerdasan kugnitif seseorang. IQ adalah interpretasi hasil tes intelegensia ke dalam angka yang dapat menjadi petunjuk mengenai kedudukan tingkat intelegensia seseorang (Azwar, 2004 dalam Tikollah, 2006). EQ adalah kemampuan mengelola emosi diri sendiri dan hubungannya dengan orang lain. Ada empat komponen yang membentuk EQ, yaitu kesadaran diri, pengeolaan diri, kesadaran sosial, dan keahlian sosial. SQ adalah adalah kecerdasan untuk menghadapi dan memecahkan persoalan makna dan nilai, yaitu menempatkan perilaku dan hidup manusia dalam konteks makna yang lebih luas dan kaya serta menilai bahwa tindakan atau jalan hidup seseorang lebih bermakna dibandingkan dengan yang lain (Zohar \& Marshall, 2004). SQ dimiliki oleh orangorang yang memahami makna, nilai, dan tujuan hidup. Indikasi dari SQ yang telah berkembang dengan baik mencakup kemampuan untuk bersikap fleksibel, adanya tingkat kesadaran diri yang tinggi, kemampuan untuk menghadapi dan memanfaatkan penderitaan, kemampuan untuk menghadapi dan melampaui perasaan sakit, kualitas hidup yang diilhami oleh visi dan nilai-nilai, keengganan untuk menyebabkan kerugian yang tidak perlu, kecenderungan untuk berpandangan holistik, kecenderungan untuk bertanya "mengapa" atau "bagaimana jika" dan berupaya untuk mencari jawaban-jawaban yang mendasar, dan terakhir memiliki kemudahan untuk bekerja rnelawan konvensi. IQ hanya menentukan $20 \%$ dari perjalanan hidup seseorang. Sisanya, ditentukan oleh kemampuan yang terkait dengan EQ dan SQ. IQ sebagai penghasil modal material, EQ sebagai penghasil modal sosial, dan SQ sebagai penghasil modal spiritual. Keseimbangan IQ, EQ, dan SQ akan memupuk dan memperkuat sifat dasar manusia, yaitu kasih, sayang, adil, dan syukur. Sifat dasar manusia tersebut akan memperkokoh ketangguhan pribadi, sosial, dan lingkungan. Ini akan menjadi ketiga ketangguhan tersebut dilandasi dengan sifat dasar manusia, yaitu kasih, sayang, adil, dan syukur. Ketangguhan pribadi menurut Agustian (2006) adalah ketika seseorang berada pada posisi telah memiliki pegangan'prinsip hidup yang kokoh dan jelas. Seseorang bisa dikatakan tangguh, apabila ia telah memiliki prinsip yang kuat sehingga tidak mudah terpengaruh oleh lingkungannya yang terus berubah dengan cepat. Ia tidak menjadi korban dari pengaruh lingkungan yang dapat mengubah prinsip hidup atau cara berpikirnya. Orang yang telah memiliki prinsip hidup yang kuat, ia akan mampu untuk mengambil suatu keputusan yang bijaksana dengan menyelaraskan prinsip yang dianutnya dengan kondisi lingkungannya tanpa harus kehilangan pegangan hidup, memiliki prinsip dari dalam diri keluar bukan dari luar ke dalam dan mampu mengendalikan pikirannya sendiri ketika berhadapan dengan situasi yang sangat menekan.Kemampuan soft skill ini sangat dibutuhkan oleh seorang auditor ketika menghadapi tekanan terhadap anggaran waktu, tingkat stressing selama proses audit. Sehingga Sistim pembelajaran matakuliah auditing secara koneptual bisa dijelaskan dalam bagan sebagai berikut :

\section{KESIMPULAN}

Proses pembelajaran ilmu Auditing tidak bisa dilepaskan dengan tuntutan dunia praktik. Penelitian-penelitian empirik menemukan banyak sekali fakta tentang proses interaksi auditor saat mengambil keputusan. Professional auditor judgment merupakan hal yang sangat penting dalam pekerjaan audit. Semua proses pekerjaan audit sangat tergantung pada auditor judgment. Sementara itu auditor judgment merupakan proses sebagai proses kognitif yang merupakan perilaku pemilihan keputusan. Kompetensi ini merupakan proses yang dapat dikondisikan dalam sebuah proses pembelajaran yang benar pada mata kuliah auditing. Dengan menggabungkan kemampuan hard skill dar soft skill daiam sebuah kurikulum maka mata kuliah auditing diharapkan akan dapat menjawab tuntutan dunia praktik audit 


\section{Gamber: \\ Pembelajaran Mata Kuliah Auditing}

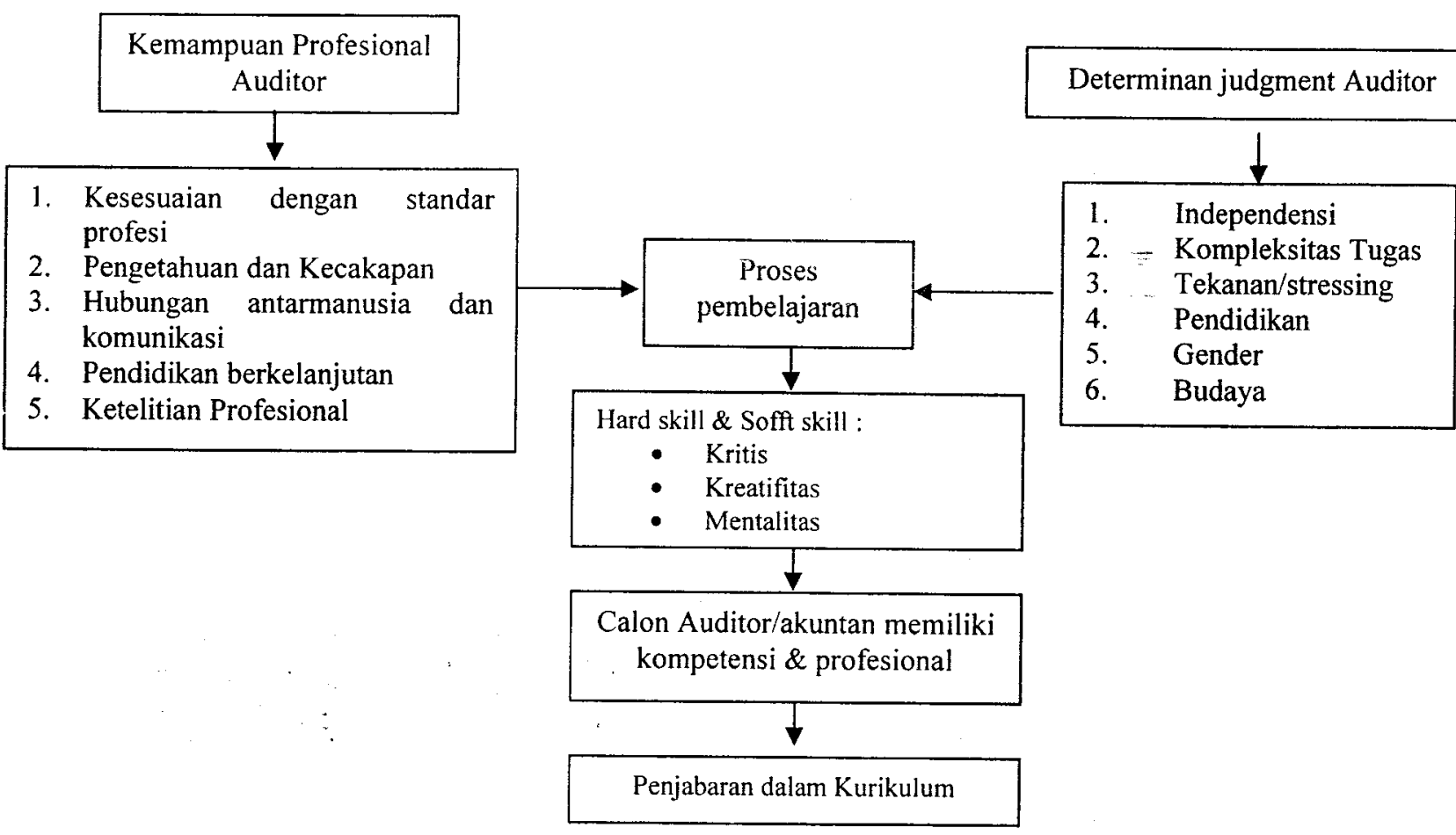

Penjabaran dalam kurikulum mata kuliah auditing secara koqnisi (hard skill) masingmasing entitas lembaga pendidikan memiliki materi yang relative sama. Namun dalam kemampuan soft skill pembelajaran menyesuaikan dengan kondisi peserta didik dan lingkungan yang melatarbelakanginya.

Konsep tentang soft skill sebenarnya merupakan pengembangan dari konsep yang selama ini dikenal dengan istilah kecerdasan emosional (emotional intelligence). Soft skill sendiri diartikan sebagai kemampuan diluar kemampuan teknis dan akademis, yang lebih mengutamakan kemampuan intra dan interpersonal.

Untuk kebutuhan kurikulum mata kuliah auditing kemampuan soft skill bisa saja

DAFTAR PUSTAKA

Abdolmohammadi, M. dan A. Wright. 1987. An examination of the effects of experience and task complexity on audit judgments. The Accounting Review 62 (January): 1-13. dijabarkan lebih detil lagi dalam dua kategori : intrapersonal dan interpersonal skill. Intrapersonal skill mencakup : self awareness (self confident, self assessment, trait \& preference, emotional awareness) dan self skill ( improvement, self control, trust, worthiness, time/source management, proactivity, conscience). Sedangkan interpersonal skill mencakup social awareness (political awareness, developing others, leveraging diversity, service orientation, empathy dan social skill. (Leadership, influence, communication, confilct management, cooperation, team work synergy)

Arens dan Loebbecke, 1996. Auditing, Diterjemahkan oleh Amir Abadi Jusuf, Jakarta: Salemba Empat.

Arum, Enggar Diah Puspa. 2004. Pengaruh Persuasi atas Preferensi Klien dan Pengalaman Audit terhadap Pertimbangan Auditor dalam Mengevaluasi Bukti Audit (Survey 
terhadap Auditoryang bekerja pada KAP di kota Bandung). Tesis Universitas Padjadjuran Bandung.

Bertens, K. 2000. Pengantar Etika Bisnis, Penerbit Kanisius, Yogyakarta.

Bonner, S.E. dan Lewis, B.L. 1990. Determinants of auditor expertise. Journal of Accounting Research Vol 28 pp. 1-20.

Budiyanto, Enjang Tachyan. 2005. Pengujian Variabel-variabel yang Berpengaruh terhadap Ekspektasi Klien dalam Audit Judgment. Tesis Program Pascasarjana Magister Sains Akuntansi Universitas Diponegoro.

Chung, J., dan G.S. Monroe.2001. A Research Note on the Effects of Gender and Task Complexity on an Audit Judgment. Behavioral Research In Accounting. Vol 13: 111-125.

Duska, Ranold .F. dan Duska, Brenda S. 2003. Accounting Ethics. Blackwell Publishing Ltd.

Ghozali, Imam. 2005. Aplikasi Analisis Multivariate dengan Program SPSS. $3^{\text {th }}$. Badan Penerbit Universitas Diponegoro. Semarang.

Gudono dan Sriwhajoeni. 2000. "Persepsi Akuntan terhadap Kode Etik Akuntan". Jurnal Riset Akuntansi Indonesia. Vol. 3, No. 2, pp. 168184.

Handoko, Hani. 2003. Manajemen. Edisi kedua. BPFE. Yogyakarta.

Hellriegel, Don dan J. W. Slocum. 1979. Organizational Behavior. USA. West. Publishing Co.

Herliansyah, Yudhi dan Ilyas, Meifida. 2006. Pengaruh Pengalaman Auditor Terhadap Penggunaan Bukti Tidak Relevan Dalam Auditor Judgment. SNA 9 Padang. 23-26 Agustus.

Indriantoro, N dan Bambang, S. 1999. Metndologi Penelitian Bisnis. Edisi Pertama. BPFE. Yogyakarta.

Jamilah dkk. 2007. Pengaruh Gender, Tekanan Ketaatan, Dan Kompleksitas Tugas Terhadap Audit Judgment. SNA X Makasar. 26-28 Juli.

Koroy, Tri Ramaraya. 2005. Pengaruh Preferensi Klien dan Pengalaman
Audit Terhadap Pertimbangan Auditor. Sva VII! Solo. 15-16 September.

Ludigdo, Unti. 2006. Strukturasi Praktik Etika di Kantor Akuntan Publik: Sebuah Studi Interpretif. SYA IX Padang. 23-28 Agustus.

Mulyadi. 2002. Auditing. Edisi enam. Saienba Empat. Jakarta.

Pflugrath Gary, Nonna Martinov-Bennie dan Liang Chen. 2007. The impact of codes of ethics and experience on auditor judgments. Managerial Auditing Journal. Vol 22, No. 6, pp. 566-589.

Pratt, J. dan J.D. Stice. 1994. The effects of client characteristics on auditors' litigation risk judgments, requiring audit evidence, and recommended audit fees. The Accounting Review, 69 (4): 639-656.

Robbins, Stephen. 2007. Organizational Behvior. $12^{\text {th }}$ edition. Pearson Education, Inc. New Jersey. dalam Diana Angelica. Perilaku Organisasi. Edisi ke Dua Belas. Salemba Empat. Jakarta. 2008.

Santosa, Purbayu Budi dan Ashari. 2005. Analisis Statistik dengan Microsoft Excel dan SPSS. Penerbit Andi. Yogyakarta.

Sasongko. www the accountant.com Diakses tanggal 16 April 2009.

Shelton, S. W. 1999. The Effect of Experience on the Use of Irrelevant Evidence in Auditor Judgment. The Accounting Review. Vol.74. No. 2. April: $217-224$.

Su'udiyah, Anis. 2005. Persepsi Akuntan dan Mahasiswa Akuntan terhadap Etika Bisnis dan Etika Profesi (Studi Empiris pada Akuntan dan Mahasiswa PPA di Jawa Tengah. Tesis Program Pascasarjana Magister Sains Akuntansi Universitas Diponegoro.

Wibowo, Agung. 2005. Pengaruh Kode Etik Akuntan, Personal Ethical Philosophy, Corporate Ethical Value terhadap Persepsi Etis dan Pertimbangan Etis Auditor. Tesis Program Pascasarjana Magister Sains Akuntansi Universitas Diponegoro. 
Wood, lack, W. Joseph, dan R. M. Zeffane.2001. Organisational Behavour. 2nd ed. Australia. John Wiley \& Sons Australia.

Zulaikha, 2006. Pengaruh Interaksi Gender,
Kompleksitas
Tugas
Dan

Pengalaman Auditor Terhadap
Audit bugnem Sotweh Rajian Eksperimental Dalan Audit Saido Akun Persediaani), SNA $L$ Paciang. 23-28 Agustus. 